\title{
Moving from pedagogical challenge to ergonomic challenge: Translating epistemology into the built environment for learning
}

\author{
Pippa Yeoman, Nathan Ashmore \\ The University of Sydney
}

\begin{abstract}
In response to an acknowledged gap in the literature - concerning a lack of actionable knowledge about the relations between the designed environment and learning activity - we make a case for moving the field forward by reframing pedagogical challenges in ergonomic terms in order to reach satisfactory epistemic resolutions. This article reflects a timehonoured way of learning through apprenticeship and was produced through the collaborative efforts of an educational researcher and a specialist in audiovisual design. Drawing on our recent participation in the redevelopment of university teaching facilities, this case study explores how educational design ideas persist over the duration of large infrastructure developments. This article offers an overview of the 16-month design process, followed by a reframing of the underlying pedagogical challenges using the activity centred analysis and design framework (Goodyear \& Carvalho, 2014), an analysis of the ergonomic solution presented in the final project documents, and a discussion of the epistemic resolution of two particularly demanding design challenges. It makes a theoretical contribution using the notion of epistemic apprenticeship to explore how educational design teams innovate in the absence of pedagogical evidence, and a methodological contribution that builds on analysis to connect epistemic intentions and pedagogical practice over time.
\end{abstract}

How does one resolve an impasse, or move beyond an acknowledged gap, in the literature? Reviews conducted between 1979 and 2011 repeatedly confirm a lack of theory and methods capable of illuminating the role of the designed environment in situated learning activity (Blackmore, Bateman, Loughlin, O'Mara, \& Aranda, 2011; Higgins, Hall, Wall, Woolner, \& McCaughey, 2005; Temple, 2007; Weinstein, 1979). One response (Barrett, Zhang, Moffat, \& Kobbacy, 2013) has been to look for correlations between environmental factors (light, sound, temperature, air quality, choice, flexibility, connection, complexity, colour and texture) and rates of learning - revealing that $16 \%$ of annual variation can be attributed to these factors alone. Another has been to compare differences in learning outcomes between students in formal and technology enhanced learning spaces, with the latter demonstrating significant positive effects (Brooks, 2010; Cotner, Loper, Walker, Walker, \& Brooks, 2013) and providing support for constructivist pedagogies already known to develop learner autonomy (Brooks \& Solheim, 2014; Imms \& Byers, 2016). Yet another approach has been to address process-oriented challenges, such as improving the alignment between pedagogy and physical space (van Merriënboer, McKenney, Cullinan, \& Heuer, 2017), providing support for interdisciplinary design (Konings, Bovill, \& Woolner, 2017), training for non-designers (Janssen, Konings, \& van Merriënboer, 2017) and increasing user participation in the lifecycle of buildings (Koutamanis, Heuer, \& Konings, 2017). Whilst each contributes something to the learning spaces literature, none satisfactorily theorise how the designed environment can be said to influence learning activity or how these effects play out across a range of educational settings. What is more, weaknesses in theorising the technologies of learning (Oliver, 2012) have limited our capacity to critically examine their role in shaping the political, economic and social aspects of education (Castañeda \& Selwyn, 2018).

Technologies for learning - be they analogue, digital or hybrid - are never neutral (Bayne, 2014). Having failed to adequately theorise the analogue, it is not surprising that increasingly complex technologies have amplified the problems associated with untheorised tools and missing methods (Sørensen, 2009). People who are practically involved in educational infrastructure redevelopment are in need of methods and tools to map the effects of change in one aspect of a design as it relates to the totality of the design, and to trace the fine-grained shifts in practice resulting from such changes, especially since these play out moment by moment at the micro scale and their longer term effects may take years to register at the macro scale (Carvalho \& Yeoman, 2018; Yeoman, 2017). As things stand, all we (researchers) have to offer those engaged in educational infrastructure redevelopment is that, beyond meeting basic human requirements to stay warm and dry, to see or be seen, to hear and be heard - it is difficult to provide action-oriented knowledge about how the designed environment shapes valued knowledge-oriented activity. This is more than a little concerning, given the scale of recent investment in the built environment for learning, including 
Australia's Building the Education Revolution at a cost of AUD\$16.2 billion (New South Wales Parliament Legislative Council, 2010) and the UK's Building Schools for the Future program at an estimated cost of between $£ 52$ and $£ 55$ billion (House of Commons Public Accounts Committee, 2009), not to mention myriad missed opportunities to create convivial environments for learning. Driven by complex social and economic forces, these investments have resulted in redesigning learning spaces being named one of the medium-term trends shaping education around the world (Adams Becker et al., 2017), despite the paucity of educational research to inform this development.

To put it bluntly, space does matter, but we lack theory and methods capable of revealing the complex mediating chains of effects that give rise to learning (Higgins et al., 2005; Weinstein, 1979). In response, this article explores the redevelopment of university teaching spaces in a large regional hospital. As authors we speak from different perspectives. We were part of a team of more than 40 academic and professional experts tasked with designing an innovative suite of learning spaces. We were quite literally learning on the job. Drawing on a range of disciplinary and professional expertise, we made our way by engaging in a form of reciprocal apprenticeship, exercising distinct but complementary knowledge practices that resulted in a satisfactory resolution of competing forces. This was far more nuanced than a series of transactional trade-offs. Our work was achieved through a subtle shift in focus, moving from the untheorised pedagogical challenge of designing new spaces for new practices into the realm of well-theorised ergonomic solutions known to support qualities of human activity that facilitate learning. It involved a bi-directional epistemic apprenticeship that produced a conceptual, material and practice-oriented synthesis.

According to Markauskaite and Goodyear (2017), to be apprenticed is to learn through imitation and as a function of actually doing the work involving:

- $\quad$ direct perception that often results in a primary artefact;

- analytical perception that is developed through the creation of a model or secondary representation; or

- epistemic perception that results in new practices or objects to be produced in the future otherwise known as a tertiary object.

The first involves a concrete problem needing a solution, the second a situation or object in need of understanding, the third a projection into the future with the aim of creating something new. This third type of perception, Markauskaite and Goodyear say, demands the fusing of professional practices - passed through observation, social interaction and material engagement - with largely invisible mental processes, including thinking, self-regulation and reflection. These practices build on, and generate, knowledge that is connected with material action and the sociopolitical concerns of communities. They depend on the development of epistemic tools to bridge between the conceptual, the social, and the material. This article represents two phases in which epistemic apprenticeships were at work. The first resulted in a suite of new learning spaces. The second produced this article - in which we use the activity centred analysis and design (ACAD) framework (Goodyear \& Carvalho, 2014) to develop epistemic tools capable of bridging the conceptual, social and material when designing for learning.

The ACAD framework supports an ecological approach to design for learning, in which learning activity is conceptualised as an emergent phenomenon. This framing highlights that learning is mediated through activity - actions, thoughts and emotions - that cannot be designed in advance, only indirectly influenced through design. In acknowledging the complex interplay of the social (Ito et al., 2015; Wenger, 1999), the material (Ingold, 2011; Lave \& Wenger, 1991; Sørensen, 2009;) and the epistemic (Clark, 2010; Hutchins, 2014) in learning, and to focus design attention on those aspects of any learning situation that are open to alteration through design, ACAD offers a theoretical scaffold with four components (see Figure 1). The first three accommodate the designable aspects of the social, material, and conceptual dimensions of learning, and the fourth accommodates the emergent activity of learners, including acts of co-creation and co-configuration. Whilst the ACAD framework certainly informed the first author's participation in the practical work of learning space redevelopment, it did not formally contribute to the (re)design process because, at the time of the redevelopment, it was itself a work in progress. However, in this article, we use the framework to retrace our steps, to explore and document the connections between design decisions we helped to make and the quality of learning activity anticipated by the broader working group. 


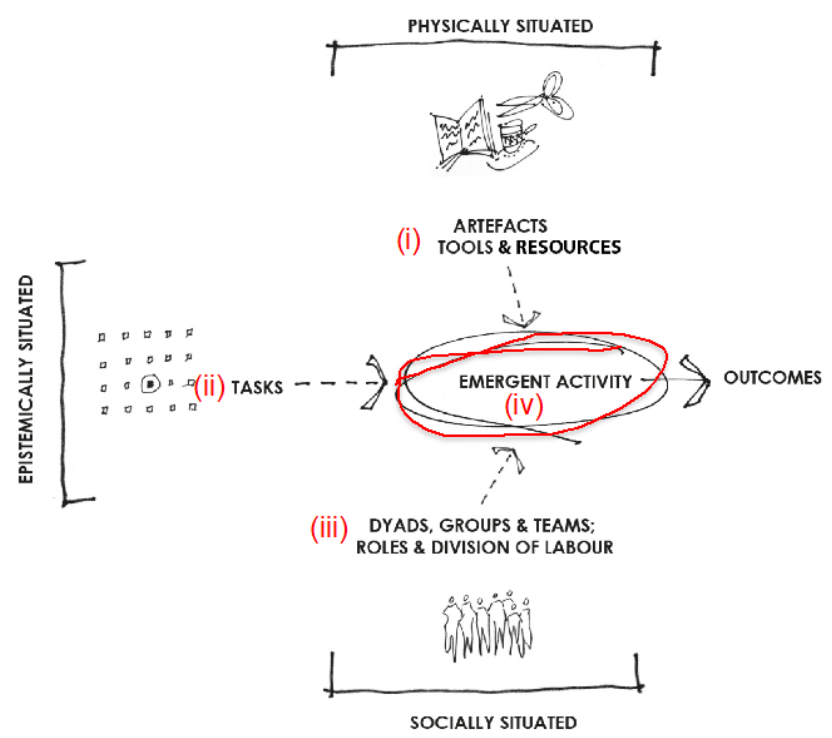

i. The set design, the structures of place, including material and digital artefacts, tools and resources.

ii. The epistemic design, the structures of knowledge and ways of knowing, including the sequence \& pace of tasks and assessment.

iii. The social design, the structures of social arrangements, such as groups, dyads, and (un)scripted roles or identities.

iv. Co-creation and co-configuration activity-emergent learning activity-highlights learner's agency to co-configure what is proposed and the ways in which the designed environment can be said to participates in teaching and learning practice.

Figure 1. The ACAD framework (Carvalho \& Yeoman, 2018, p. 7)

Our aims in writing are twofold. The first is to make a theoretical contribution using the notion of epistemic apprenticeship to explore how educational design teams innovate in the absence of evidence. The second is to make a methodological contribution through the creation of epistemic tools (see Tables 4, 5 and 6) that bridge the conceptual, social and material aspects of the design, and the design with the anticipated quality of future learning activity it is intended to support. We argue that the epistemic apprenticeship through which we created these tables, and the tables themselves, offer the beginnings of a method capable of productively mapping the relations between the designed environment and situated learning activity: during design, at handover, in use, during evaluation, and to inform future (re)design. Carried out with the approval of the hosting university, this work involved participant observation and reflection on professional practice during the 16-month design process, analysis of project documents, and reflection on challenges encountered in the first 6 months after occupation of the learning spaces. It is presented in four moves, starting with an overview of the design process, followed by a reframing of the underlying pedagogical challenges using the ACAD framework, an analysis of the ergonomic solution presented in the final concept design and function brief, and a discussion of the epistemic resolution of two particularly demanding design challenges.

\section{Design process - an overview of the 16-month redevelopment}

The practical work on which we are drawing involved redesigning the teaching spaces on level 1 in the Westmead Education and Conference Centre (WECC). As this got underway another, much larger, project received approval for completion in 2020. As a result, the redevelopment of the WECC (see Figure 2) also became an innovation incubator for learning spaces across the Westmead precinct more broadly. The group assembled included architects, academics from a range of disciplines, representatives from professional bodies, professional university staff, and a number of different external contractors. Meetings ranged in size from well over 40 to sometimes fewer than 10. Neither of us attended every meeting. The first author's input is based on over 100 hours of participant observation in 35 meetings. The second author was responsible for translating the functional brief into a number of potential solutions, before overseeing the final audiovisual implementation. Table 1 provides an overview of the five initial workshops that produced the documents analysed in this article: the functional brief and the concept design. In practice, there was some blurring of lines between the two projects in terms of vision and the concept design but the deadlines and budgets for the smaller WECC redevelopment were much tighter and provide the focus for this article. 


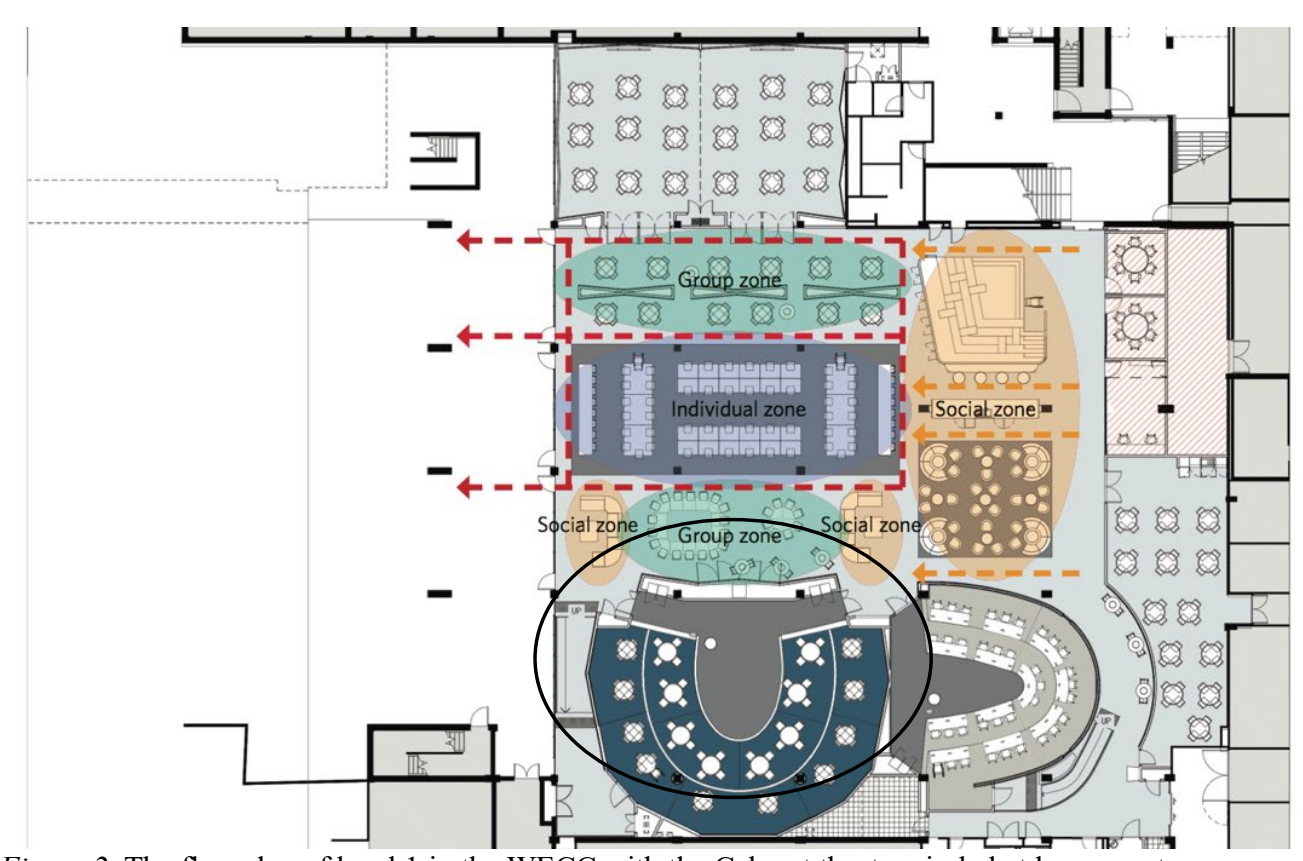

Figure 2. The floorplan of level 1 in the WECC with the Cabaret theatre circled at lower centre

There was a sense of cautious optimism at the start of the first visioning session (May 2016). The group had been asked to submit images of inspiring spaces, and the facilitator led a discussion about aspects of each, before the project leader spoke of spaces he had visited and the extent of his vision for the project. One space had clearly catalysed his imagination - the Cabaret Theatre at the Karolinska Institute in Sweden (see Figure 3). A number of others in the group had subsequently visited this space. The combined effect of this experience, their standing in the community, and their ability to communicate the type of learning activity the space would support, established an early mandate to design something out of the ordinary. This ultimately shaped the suite of spaces that distinguishes this redevelopment (see Figure 2). Anchored in the spatial imaginary of the Cabaret Theatre, the resulting vision as presented in the final concept design is summarised in Table 2.

Table 1

Overview of the initial participatory design workshops held in 2016

\begin{tabular}{lll}
\hline Workshop & Aims & Output \\
Misioning 2016 & $\begin{array}{l}\text { Establish a shared vision and agree on } \\
\text { teaching and learning activities/ } \\
\text { modalities, and workspace activities. }\end{array}$ & $\begin{array}{l}\text { Aspirational vision statement } \\
\text { for the project }\end{array}$ \\
\hline $\begin{array}{l}\text { Thematic deep dive } \\
\text { June 2016 }\end{array}$ & $\begin{array}{l}\text { Establish user requirements: cohort size, } \\
\text { teaching and learning and workspace } \\
\text { activities/modalities. }\end{array}$ & $\begin{array}{l}\text { Functional relationship diagram, } \\
\text { and draft schedule of } \\
\text { accommodation }\end{array}$ \\
\hline $\begin{array}{l}\text { Codesign / Synthesis } \\
\text { June 2016 }\end{array}$ & $\begin{array}{l}\text { Consider initial architectural sketches } \\
\text { giving thought to efficiencies of space and } \\
\text { agree on the schedule of accommodation. }\end{array}$ & $\begin{array}{l}\text { Finalise schedule of } \\
\text { accommodation, draft functional } \\
\text { brief. }\end{array}$ \\
\hline Validation & $\begin{array}{l}\text { Review concept design options, assess, } \\
\text { and select preferred option. Architects to } \\
\text { present the functional design brief. }\end{array}$ & $\begin{array}{l}\text { Issue final functional brief. } \\
\text { July 2016 }\end{array}$ \\
$\begin{array}{l}\text { Review and endorse the functional design } \\
\text { brief and concept design. }\end{array}$ & $\begin{array}{l}\text { Endorse functional brief and } \\
\text { concept design. }\end{array}$ \\
\hline July 2016 & &
\end{tabular}


Table 2

Vision for the new WECC as documented in the final concept design (July 2016)

Vision
The WECC will be a reconfigurable space for
knowledge transfer, collaboration and awareness
in research, teaching and learning in healthcare.
It will stimulate excitement and revitalise
teaching and learning and be an expression of the
partnership between the university and associated
hospitals.

It will inspire a refreshing of teaching and learning practice, intra-professional learning, an experimental outlook, pride, and the realisation of similar values held by all stakeholders.

\section{Qualities}

- a healthy environment (light, air, views, green space),

- $\quad$ attractive support functions (coffee, support services),

- dynamic (adjusting to size, time, activities), engaging (attractive, exciting),

- human in scale and lacking a strict spatial hierarchy,

- durable (maintenance),

- $\quad$ sensitive to both historical and natural context,

- and a longing for a local "home base" for those who worked across multiple contexts.

Developing a vision requires an ability to think about or plan the future with imagination or wisdom. It calls for a mental image of what that future could be (Oxford English Dictionary, 2018). Translating a vision into the built form is something architects have done for centuries. But the missing piece of this puzzle is the link between the designed environment and subsequent learning activity. How does a reconfigurable space support the aspirations named in the vision above? Part of the answer lies in clearly articulating the difference between a property and a quality. The first is commonly used to refer to the measurable attributes of physical matter, whilst the second references the characteristic observable effects of some thing. But this distinction serves to separate materials from their effects, resulting in a false dichotomy between immutable (objective) properties and the (subjective) qualities used to describe the effects of certain properties as perceived and experienced in use, leaving us blind to the qualities of properties expressed in motion. And, if we are to honour the situative nature of learning, then finding the missing link must depend on doing more than understanding utility or what technologies can do for us. In what follows we explore one way of tracing the entanglement of people, pedagogy and place that gives rise to productive learning activity.

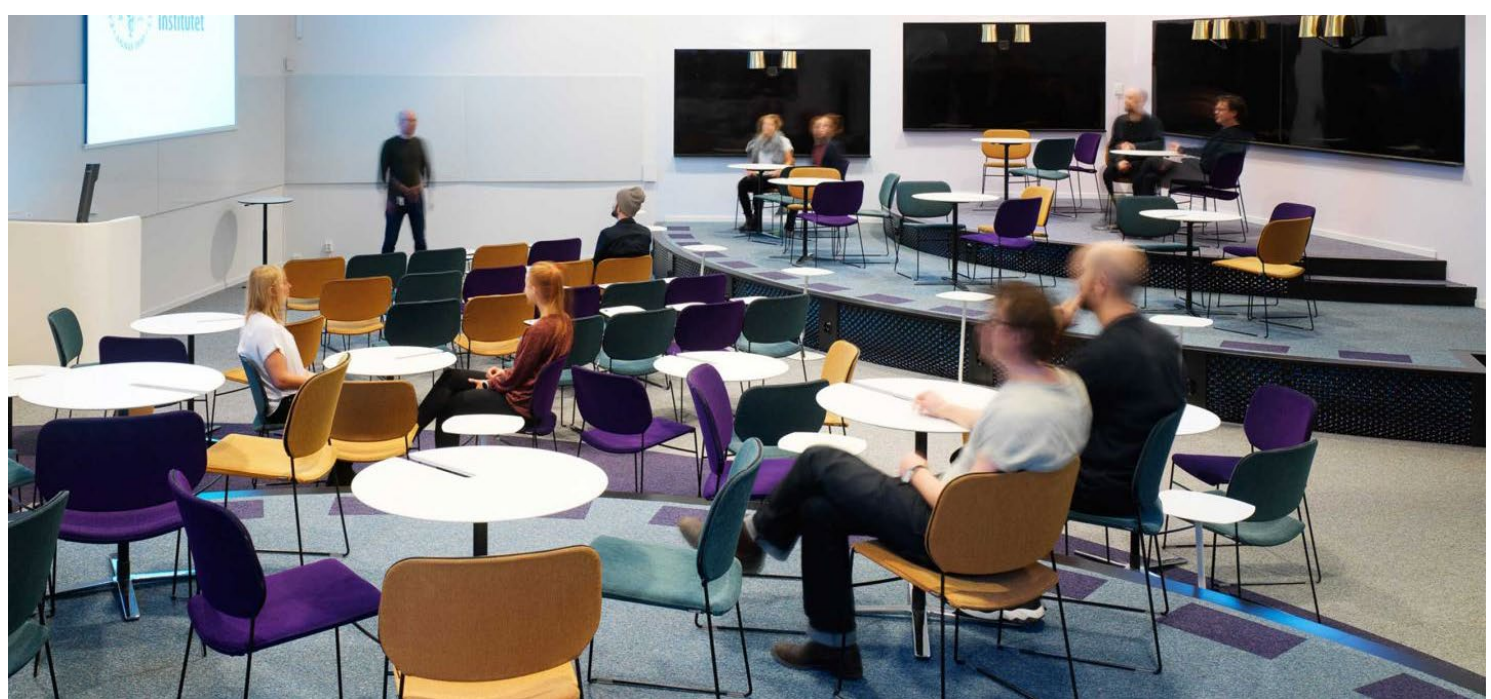

Figure 3. The original Cabaret Theatre - for learning - at the Karolinska Institute, Stockholm, Sweden

Prior to finalising the functional brief, the individual responsible for developing the Cabaret Theatre at the Karolinska Institute was invited to participate in workshop 3 (the Codesign/synthesis workshop, June 2016). He encouraged the group to craft a concise action-oriented list of learning performance requirements, against which all design decisions could be weighed. The three he relied on were dialogue, visualisation, and peer to peer. These are listed in the introduction to the final functional brief (September 2016). However, further into the document, they are recast as evaluation criteria for each of the different 
space typologies, and it is worth noting how they have been reframed (see Table 3). Dialogue and the quality of communication (auditory and visual) are the overlapping but actionable criteria. But the other two more aspirational statements are less actionable in terms of evaluation. In what follows, we document our process of sense-making, or the bi-directional epistemic apprenticeship through which we crossed the theoretical divide, moving from pedagogical problem, to ergonomic challenge, to elegant epistemic resolution.

Table 3

Evaluation criteria for the Cabaret Theatre as described in the functional brief

\begin{tabular}{ll}
\hline Dialogue & $\begin{array}{l}\text { Within and between groups of 3-4, and both "parliamentary" debate } \\
\text { and whole-of-group discourse with long monologue possible. }\end{array}$ \\
\hline $\begin{array}{l}\text { Clarity and quality of } \\
\text { communication }\end{array}$ & $\begin{array}{l}\text { Within groups without straining, and only slightly more effort to } \\
\text { address the room. Audio amplification for distributed modes. }\end{array}$ \\
\hline $\begin{array}{l}\text { Supporting innovation in } \\
\text { learning and research }\end{array}$ & A novel space that focuses on creating connection between groups. \\
\hline $\begin{array}{l}\text { Supporting learning and } \\
\text { research through fostering } \\
\text { interactions }\end{array}$ & $\begin{array}{l}\text { Supports active learning in small groups, based on high quality } \\
\text { interaction between participants. }\end{array}$ \\
\hline
\end{tabular}

\section{Reframing the pedagogical problem}

The analysis for this article was conducted 6 months after the initial occupation of level 1 of the WECC. Our aim was to examine the confluence of factors that resulted in a good resolution of competing forces. Whilst the criteria in Table 3 support the type of learning activity envisaged, they do not communicate the richness of the design nor do they explain how these properties would support valued forms of learning activity. This poses a risk in terms of lost history, which in turn increases the challenges associated with communicating the original design intentions to successive generations of users and creates a blunt instrument for evaluation. Fashioning an elegant design that supports dialogue, communication, innovation and interaction means understanding how these criteria are expressed and supported in unfolding learning activity. For example, if we focus on dialogue, it is possible to provide a positive evaluation of a far less innovative space using the description in Table 3. We argue that using criteria such as this, stripped of the rationale for their development, contributes to ineffective handovers and post occupancy evaluations. In reframing them using the ACAD framework we highlight how each is supported by the totality of the design - set, social and epistemic - and expressed in a quality of emergent learning activity that is valued, as detailed in Table 4.

Table 4

Final design expressed in terms of the ACAD framework

Epistemic design The Cabaret Theatre is an innovative spatial design intended to support increasingly participatory forms of learning and active collaboration. This will involve learners moving between short didactic presentations, group work, moments of individual reflection, debates, and plenary sessions.

Social design Group learning activity is to be supported in a single group ( $\max 84)$ or in multiple smaller groups (up to 18 of between $4-6$ ) and productive facilitation will not depend on spatial hierarchies to exercise control.

Set design Shifting between activity types should not result in significant loss of time due to the need to move between spaces or significantly reconfigure furnishings. This will require sensitive audiovisual solutions and a reduction in elements that cue traditional didactic hierarchies.

Capturing the underlying design intentions using the three designable dimensions of the ACAD framework addresses the risk of losing the rich history of the design, but does not make the task of evaluation any easier. A case could be made for using both Table 3 and Table 4 to guide evaluation. But only the first of the four criteria listed in Table 3 is unambiguously stated as a noun. Stating evaluation criteria in noun form does more than give them substance or an identity within a particular class of people, places or things. It lays the groundwork for making it possible to connect desired qualities of learning activity with designed properties of the learning environment. Based on this, we have restated the original evaluation criteria as 
follows: The design of the Cabaret Theatre will support and enhance mobility, dialogue, and connection in the service of innovative learning and research. None of these criteria fall exclusively into a single dimension of design but each is expressed as a particular quality of learning activity across all three: see Table 5.

Table 5

Restated evaluation criteria expressed in terms of the ACAD framework

\begin{tabular}{|c|c|c|c|}
\hline & Set design & Social design & Epistemic design \\
\hline Mobility & $\begin{array}{l}\text { Ability to reconfigure } \\
\text { groups without } \\
\text { reconfiguring space or } \\
\text { losing sight of shared } \\
\text { points of visual attention } \\
\text { and move about with ease. }\end{array}$ & $\begin{array}{l}\text { Ability to re-convene in } \\
\text { assorted group sizes during } \\
\text { learntime and switch } \\
\text { between assorted co- } \\
\text { constructed points of visual } \\
\text { attention. }\end{array}$ & $\begin{array}{l}\text { Ability to move between } \\
\text { different types of learning } \\
\text { activity including task } \\
\text { rotations, demonstrations, } \\
\text { sketching, debates and } \\
\text { plenary sessions. }\end{array}$ \\
\hline Dialogue & $\begin{array}{l}\text { Audio amplification and } \\
\text { acoustic design to support } \\
\text { vocal clarity in distributed } \\
\text { modes and plenary } \\
\text { sessions, in person and } \\
\text { remotely. }\end{array}$ & $\begin{array}{l}\text { Speech should be } \\
\text { comfortable within groups } \\
\text { of } 3-4 \text {, between these } \\
\text { groups, and across the } \\
\text { whole, in person and with } \\
\text { far-end participants. }\end{array}$ & $\begin{array}{l}\text { Active learning in groups, } \\
\text { with a focus on high } \\
\text { quality verbal interaction } \\
\text { supported by points of } \\
\text { shared visual attention, in- } \\
\text { person and remotely. }\end{array}$ \\
\hline Connection & $\begin{array}{l}\text { Maximise lines of sight } \\
\text { across room and eye- } \\
\text { contact within groups. AV } \\
\text { to enhance human co- } \\
\text { presence and orchestration } \\
\text { without asserting spatial } \\
\text { dominance. }\end{array}$ & $\begin{array}{l}\text { Creating connections in } \\
\text { strict hierarchical social } \\
\text { settings is challenging. } \\
\text { This space will require new } \\
\text { social norms capable of } \\
\text { supporting generative } \\
\text { learning activity. }\end{array}$ & $\begin{array}{l}\text { The educational rationale } \\
\text { of this space is to increase } \\
\text { opportunities for } \\
\text { connection by supporting } \\
\text { new spatial forms of } \\
\text { teaching, learning and } \\
\text { research practice. }\end{array}$ \\
\hline
\end{tabular}

Thus far we have demonstrated the value of expressing design intentions in succinct but rich language that accounts for the fact that learning is physically, socially, and epistemically situated; provided the rationale behind expressing evaluation criteria in noun form; and explored the restated evaluation criteria with reference to the ACAD dimensions of design. In what follows, we demonstrate the power of this particular epistemic apprenticeship by mapping aspects of the final set design (ergonomic solution) to the qualities of learning activity each supports (pedagogical challenge), in relation to mobility, dialogue and connection (epistemic resolution).

\section{Exploring the ergonomic solution}

We offer Table 6 as a product of our epistemic apprenticeship. We argue it takes the form of an epistemic tool that bridges the conceptual, social, and material challenges of designing for learning

Table 6

Properties of the set design and the quality of learning activity they support with respect to each of the restated evaluation criteria

\begin{tabular}{|c|c|c|c|}
\hline Property & Quality (mobility) & Quality (dialogue) & Quality (connection) \\
\hline $\begin{array}{l}\text { Tiered } \\
\text { flooring }\end{array}$ & $\begin{array}{l}\text { Demarcates different } \\
\text { zones of activity, holds } \\
\text { loose furnishings in } \\
\text { desired form, and } \\
\text { facilitates movement in } \\
\text { the space. }\end{array}$ & $\begin{array}{l}\text { Improves lines of sight by } \\
\text { raising the level of those } \\
\text { seated in two stages, } \\
\text { makes it easier to see who } \\
\text { is talking. }\end{array}$ & $\begin{array}{l}\text { Improved sight lines } \\
\text { enhance eye contact, } \\
\text { circular orientation invites } \\
\text { participation through } \\
\text { multiple points of shared } \\
\text { attention. }\end{array}$ \\
\hline $\begin{array}{l}\text { Small, circular } \\
\text { tables }\end{array}$ & $\begin{array}{l}\text { Diameter accommodates } \\
\text { personal digital devices } \\
\text { but does not impede } \\
\text { movement in and around } \\
\text { the tables. }\end{array}$ & $\begin{array}{l}\text { Diameter supports strong } \\
\text { internal focus and does } \\
\text { not impede an outward } \\
\text { focus. }\end{array}$ & $\begin{array}{l}\text { The strong internal focus } \\
\text { of small groups and their } \\
\text { position within a wider } \\
\text { array supports alternating } \\
\text { patterns of dialogue over } \\
\text { time. }\end{array}$ \\
\hline
\end{tabular}




\begin{tabular}{ll}
\hline Central & Provides a strong central \\
performance & point of attention that is \\
space & open (free to move into) \\
& and shared (not \\
& hierarchical).
\end{tabular}

Generous Provides for movement

allocations of between tables and group

space (2.5 to 3 formation at the

sqm per

student)

Movement into the
performance space
indicates whole group
discussion. Absence
leaves it open to other use
or for circulation.

Supports multiple groups at different stations or a single group (initial feedback suggests it's too generous).
Distance from the
performance centre to the
forward edge of the upper
tier supports the visual
reading of faces and vocal
projection without
amplification.
Many people doing
different things can make
for an overwhelming
environment, space
between groups is
intended to support co-
present activity.
Spaces with well-designed

\begin{tabular}{ll}
\hline Acoustic & Movement creates noise. \\
treatment & Managing acoustic \\
& disturbance is therefore \\
& necessary if learners are to \\
& be allowed to move. Too \\
& much noise will result in \\
& movement being curtailed, \\
& behaviourally.
\end{tabular}

\begin{tabular}{ll}
\hline Light weight & Supports reconfiguration \\
loose & without posing a risk of \\
furnishings & injury from the tiered \\
& flooring. Flexible doesn't \\
& mean wheels.
\end{tabular}

\begin{tabular}{ll}
\hline Wall and & Ceiling-mounted \\
ceiling & confidence display for the \\
mounted & stage area allows \\
digital screens & movement and local \\
& reference for the \\
& presenter.
\end{tabular}

\begin{tabular}{ll}
\hline Ceiling- & Supports real-time \\
mounted & demonstration of prepared \\
visualiser & and improvised \\
& educational materials.
\end{tabular}

\begin{tabular}{lll}
\hline $\begin{array}{l}\text { Ceiling- } \\
\text { mounted } \\
\text { microphones }\end{array}$ & $\begin{array}{l}\text { Distributed microphones } \\
\text { allow pick-up of all group } \\
\text { working areas without the } \\
\text { need to juggle multiple } \\
\text { wireless microphones } \\
\text { between learners. }\end{array}$ & $\begin{array}{l}\text { Integration with ceiling } \\
\text { speaker zones allows a } \\
\text { 'voice lift' system to } \\
\text { maintain a conversational }\end{array}$ \\
& $\begin{array}{l}\text { level during class } \\
\text { activities. }\end{array}$ \\
\hline $\begin{array}{l}\text { Distributed } \\
\text { and zoned } \\
\text { ceiling }\end{array}$ & $\begin{array}{l}\text { audience voices without } \\
\text { speakers }\end{array}$ & $\begin{array}{l}\text { Enhances dialogue } \\
\text { through localised audio } \\
\text { microphone. }\end{array}$ \\
& & $\begin{array}{l}\text { coverage of microphones } \\
\text { outside of the local "zone" } \\
\text { in which the speaker is } \\
\text { mounted (mix-minus) }\end{array}$
\end{tabular}

Large spaces with hard,
reflective surfaces and
little absorption increase
reverberation, and when
combined with
inappropriately controlled
background noise will
result in reduced
intelligibility of speech
communication.
By aggregating or
distributing chairs and
tables it is possible to
support different groups
sizes and shapes.

Large mobile displays create barriers. All large visualisation equipment is installed on the horizontal and vertical peripheries of the space leaving an open interior.

Enlarges detail and allows

for physical gestures to create an enhanced dialogue between facilitator and audience. acoustics aim to support connection without diminishing the intended use of a space - however present challenges in terms of the inherent conflict in the way that surfaces are used, and fixtures placed.

Loose furnishings support 'odd' group sizes, which promotes inclusion on the fly and accommodates groups that expand and contract over time.

Clear sightlines to a single content source via a primary large display and relay displays for those on the periphery of the space, accommodating a suitable viewing outcome for the majority of learners.

Extends the physical space and objects to remote participants to improve engagement between facilitator, content and audience.

Microphone coverage for facilitator and audience supports human connection within the room, historically (recorded) and remotely. Increasing amplification of a speaker on one side of the room to 'normal' speaking volume on the other minimises perceptual distance between audience members. 


\begin{tabular}{|c|c|c|c|}
\hline $\begin{array}{l}\text { Minimal } \\
\text { lectern }\end{array}$ & $\begin{array}{l}\text { Provides practical support } \\
\text { in terms of orchestration } \\
\text { but reduces the tendency } \\
\text { to remain in a single } \\
\text { physical location. }\end{array}$ & $\begin{array}{l}\text { Promotes movement to } \\
\text { support interactive } \\
\text { dialogue rather than fixed, } \\
\text { one-to-many monologues. }\end{array}$ & $\begin{array}{l}\text { No barrier between } \\
\text { facilitator and students, } \\
\text { diminished spatial } \\
\text { hierarchy. }\end{array}$ \\
\hline $\begin{array}{l}\text { Wireless } \\
\text { presenter for } \\
\text { PC }\end{array}$ & $\begin{array}{l}\text { Supports digital sharing of } \\
\text { presentations whilst } \\
\text { physically roving in the } \\
\text { space. }\end{array}$ & $\begin{array}{l}\text { Shared point of visual } \\
\text { attention being discussed } \\
\text { can be advanced from } \\
\text { around the room. }\end{array}$ & $\begin{array}{l}\text { Connection developed } \\
\text { through facilitation, } \\
\text { supported by roving and } \\
\text { shared points of visual } \\
\text { attention. }\end{array}$ \\
\hline $\begin{array}{l}\text { Wireless belt } \\
\text { pack with } \\
\text { Lavalier } \\
\text { microphone }\end{array}$ & $\begin{array}{l}\text { Provides hands free } \\
\text { speech reinforcement for } \\
\text { roving facilitators. }\end{array}$ & $\begin{array}{l}\text { Provides consistent high } \\
\text { quality audio for remote } \\
\text { students and recordings. }\end{array}$ & $\begin{array}{l}\text { Ensures orchestration via } \\
\text { collective auditory } \\
\text { attention is uniform. }\end{array}$ \\
\hline $\begin{array}{l}\text { Wireless } \\
\text { handheld } \\
\text { microphone }\end{array}$ & $\begin{array}{l}\text { Provides ad hoc wireless } \\
\text { speech reinforcement } \\
\text { anywhere in the room. }\end{array}$ & $\begin{array}{l}\text { Provides high quality, ad } \\
\text { hoc wireless speech } \\
\text { reinforcement for anyone } \\
\text { in the room and backup } \\
\text { for facilitator if necessary. } \\
\text { It is also useful for quiet } \\
\text { presenters to improve } \\
\text { audio signal. }\end{array}$ & $\begin{array}{l}\text { Provides amplification of } \\
\text { a single voice within the } \\
\text { cohort to focus attention } \\
\text { for all. }\end{array}$ \\
\hline $\begin{array}{l}\text { Wireless } \\
\text { screen sharing } \\
\text { from mobile } \\
\text { devices }\end{array}$ & $\begin{array}{l}\text { Supports the sharing of } \\
\text { digital images and } \\
\text { documents from anywhere } \\
\text { in the space, for multiple } \\
\text { participants } \\
\text { simultaneously. }\end{array}$ & $\begin{array}{l}\text { Promotes movement to } \\
\text { support interactive } \\
\text { dialogue and allows } \\
\text { both/all parties to share } \\
\text { their content. }\end{array}$ & $\begin{array}{l}\text { Supports a diminished } \\
\text { hierarchy in terms of } \\
\text { sharing points of visual } \\
\text { attention. }\end{array}$ \\
\hline $\begin{array}{l}\text { Wheelchair } \\
\text { access via } \\
\text { ramp }\end{array}$ & $\begin{array}{l}\text { Supports disability access } \\
\text { to the upper tier. }\end{array}$ & $\begin{array}{l}\text { Supports shared dialogue } \\
\text { for all at blackboards. }\end{array}$ & $\begin{array}{l}\text { Supports connection } \\
\text { through access to space } \\
\text { and tools. }\end{array}$ \\
\hline
\end{tabular}

\section{Understanding the epistemic resolution}

\section{Design challenge 1: orchestrating learning in the round}

Most participants in the design process could imagine a style of teaching described as roving-facilitation. It is not novel in medical settings. The difficulty came from overt challenges to traditional hierarchies that decentred the expert in the room by removing the traditional lectern and providing multiple displays around the room. This two-pronged approach was a deliberate attempt to use the designed environment (set design) to shift teaching and learning practice (epistemic design) and it highlighted the tension between the clearly articulated vision of learning through shared endeavour (social design) and what would be necessary to achieve it. Concerns were expressed in very practical terms: Where would the lecturer stand? Where would they put their teaching materials and how would they orchestrate the projection of content onto multiple screens? The lectern had come to represent an outdated mode of teaching, and its removal became an important symbolic commitment to change. In many respects this was impractical, and the careful resolution of this tension exemplifies the apprenticeship that led to an elegant epistemic resolution of a number of complex competing forces.

What was needed was a robust digital connection from where the facilitator could preview and control a number of audiovisual sources without impairing lines of sight or limiting their mobility. The architect proposed a small, fixed podium based on a digital kiosk (see Figure 4). The audiovisual components to support teaching at this location included an HDMI fly-lead for portable devices, power, USB inputs to the resident computer, a touch panel, preview monitor and a fixed microphone input. The gooseneck microphone typically found on a lectern was removed, and facilitators were provided with wireless microphones. This alteration offered support for mobility but posed certain practical risks in terms of maintaining the quality of dialogue and increasing the orchestrational load of managing the space. 

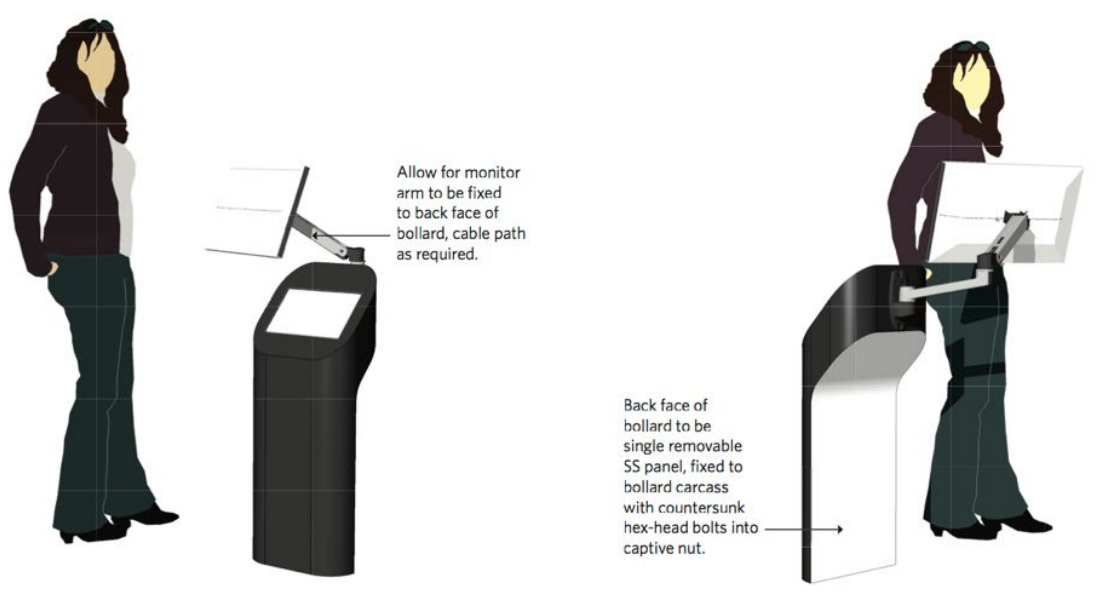

Figure 4. The minimal podium designed to support orchestration in the Cabaret Theatre in the WECC

Designed to promote innovative forms of teaching and learning, every effort was made to ensure that orchestrating learning activity in the Cabaret would be as intuitive as possible. Part of the solution involved using a university-standard, touch panel user interface and familiar software on the resident computer. The resulting podium differs significantly from conventional lecterns, but the standard digital interface provides familiarity of function and supports the innovative epistemic design of the space. The desire for this space to be defined by human co-presence resulted in the selection of an array of ceiling microphones, providing adequate pickup for certain forms of dialogue within the room. However, a constant high-quality microphone was necessary to support other forms of dialogue across this room and with remote participants as well. This need for roving audio amplification resulted in the addition of wireless microphones, but their performance depends on them being returned to charging cradles at the end of the day. As such, accommodating mobility in the set design, without alterations in teaching and learning practice, could result in a lack of connection and failed dialogue, both locally and remotely, which would negatively affect the underlying epistemic intentions of the design as a whole. This challenge can be mitigated through the provision of a fixed microphone that can be plugged into the podium, should both wireless microphones lose charge. Assessing the ways in which each aspect of sound amplification is being used in teaching and learning practice will be a major part of the ongoing review.

The process of deconstructing the lectern resulted in the table-mounted visualiser, originally located at the teaching point, being replaced with a ceiling-mounted solution placed upstage and centre. This reduced the footprint of the podium and supported the visualisation of a larger range of objects, including human demonstrations. A familiar set of symbols to control the visualiser was installed on the podium interface, but decoupling the controls and camera created challenges only fully appreciated after installation. Challenges included the absence of physical indicators of the visualiser's presence, difficulty locating the field of visualisation for those who knew it was there, and the loss of object-oriented lighting necessary to support camera capture. Whilst documented in the brief, which expressed a commitment to providing a consistent user experience, this variation required untested post hoc changes. Navigating from pedagogical opportunity to satisfactory ergonomic resolution in the set design called for keener epistemic fluency than we had collectively developed to that point. Our aims in presenting design challenge 1 were to highlight the role of epistemic perception, to trace its development through observation, social interaction and material engagement, and to demonstrate how this process resulted in the creation of epistemic tools that support invisible mental processes such as thinking, self-regulation and reflection (Markauskaite \& Goodyear, 2017) which, in this instance, act to bridge conceptual and material form.

What we learn from design challenge 1 is that driving epistemic change, through set design alone, provides a blunt instrument. Successful alterations in practice require accommodations across multiple dimensions of design and scale levels. If we value mobility, then we must make provision for audio amplification on the move. If we value dialogue, then we must make provision for, and remember to recharge, wireless 
microphones. If we value learning through moments of shared visual attention, then we must navigate the tensions between innovation and functionality. In the design phase, the drive for change came from the epistemic dimension and it created challenges in the set design. In the implementation phase, the impetus for change will come from this new set design, which will create challenges in the epistemic and social dimensions. Simply put, for these new spaces to work as intended, alterations to task structures and social interactions will be necessary across scale levels from single seminar, to unit of study, and degree structure. As such, the role of orchestrating learning in complex ecologies of learning must be viewed as an ongoing process. We argue that, in documenting and mapping these challenges with reference to the project vision, evaluation criteria and ACAD dimensions of design, we have provide insight into the relations between educational design and situated learning activity in a manner that supports the transfer of original design intentions into ongoing teaching and learning practice.

\section{Design challenge 2: learning in-person and at a distance}

The Cabaret Theatre was to be a space for learning through co-present human activity, and it was the quality of this shared dialogue - conducted with reference to points of shared visual attention - that was to set it apart. But, as the concept took shape, there was a growing sense that, whilst what went on in the room was of primary importance, remote others could be accommodated as well. This impulse to include remote access quickly became more ambitious and drove the requirement to concurrently connect other similar spaces using a range of digital technologies.

To support the desired fidelity of this type of in-person and remote device-mediated dialogue, an array of directional microphones was placed in the ceiling above the arc created by the raised tiers (see Figure 5), and radio microphones were supplied to support roaming facilitators. It is relatively easy to trace the productive relations between the epistemic design (active participatory learning) and set design (amphitheatre). But this social and epistemic design (groups of talking students with access to shared writable surfaces) created challenges in the set design (speech reinforcement vs writable surfaces). Facilitating clear auditory dialogue and shared sense-making using hard vertical surfaces for sketching and projection was a much more nuanced task than navigating preferences for different forms of technology one that exceeded our collective epistemic perception at the time. A consultant was engaged to model the electro-acoustic response of the proposed audio system and provide recommendations for acoustic treatments (absorption and diffusion) more generally. This resulted in an overall reduction in writable surfaces and the introduction of a voice-lift system, to amplify each microphone's pickup to different zones based on distance, supporting local and remote intelligibility of audience speech without interruptions caused by passing wireless microphones.

Another challenge that became more pressing with increasing requirements for visual connection at a distance was the disruption of sightlines caused by structural pillars (see Figures 5 and 6). Potential solutions included the use of multiple interactive displays on the outer walls and mobile solutions on the inner-tiers. After much debate, it was agreed that this quantity and style of technology (set design) would erode the desired quality of learning activity expressed in the notions of dialogue and connection (epistemic and social designs). As a result, analogue blackboards were selected, rather than an assortment of interactive digital displays. This choice was based on a comparison of technologies and how they would support the rapid proliferation of ideas in group settings. But the boards installed have two material properties that have significantly reduced their effective enrolment in teaching and learning practice. They have a glossy top coat that produces specular reflections from internal lighting, reducing the clarity of content viewed by users and cameras. In addition, their dark colour (selected to improve contrast and therefore visibility) requires special markers that are difficult to source and erase. Modifications to address the glossy top coat have not been considered, due to budgetary constraints. The need for different markers will require changes in operational processes and a willingness of users to adapt to changing material circumstances. 


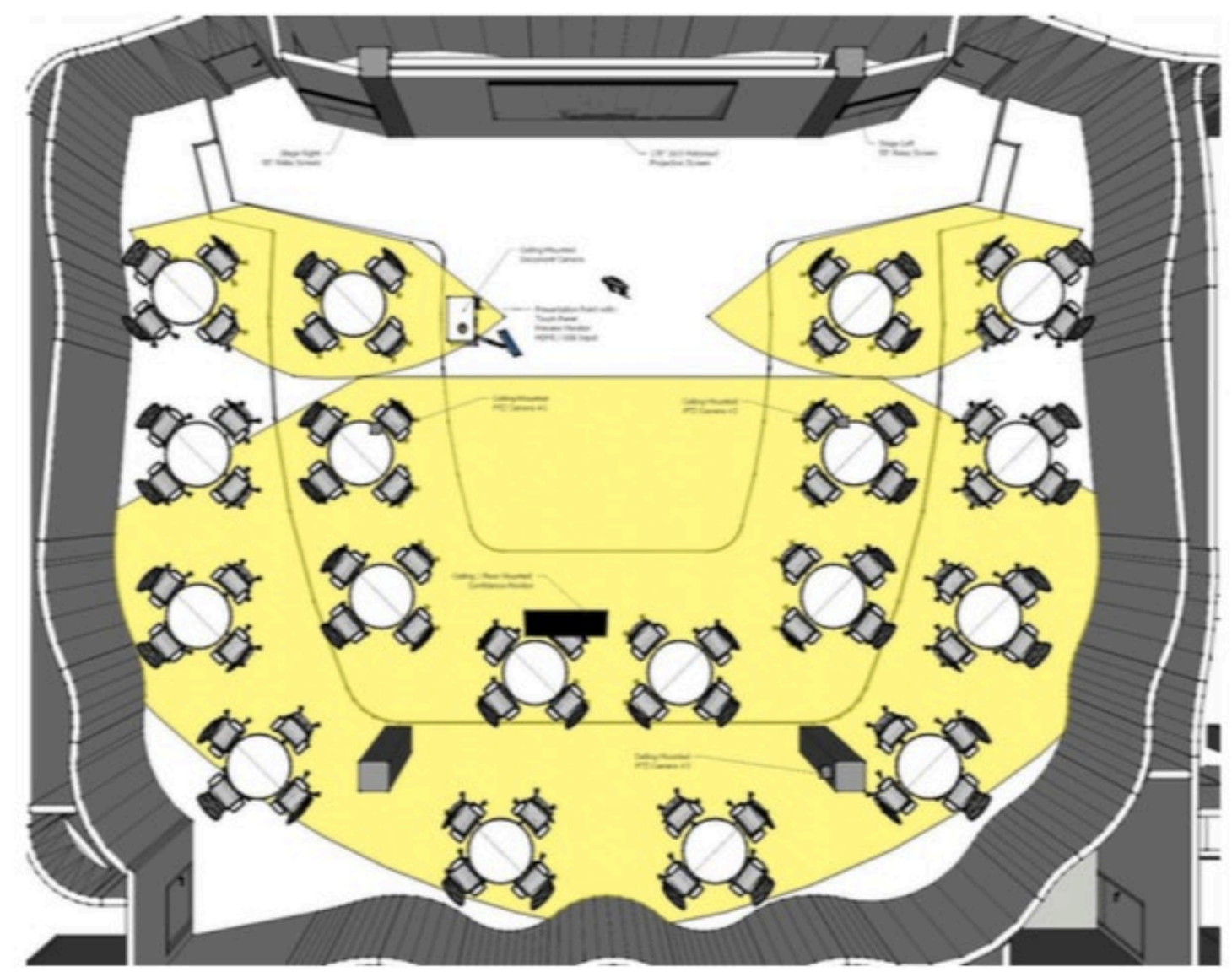

Figure 5. Floorplan of the Cabaret Theatre showing audiovisual and teaching locations and the viewing areas study

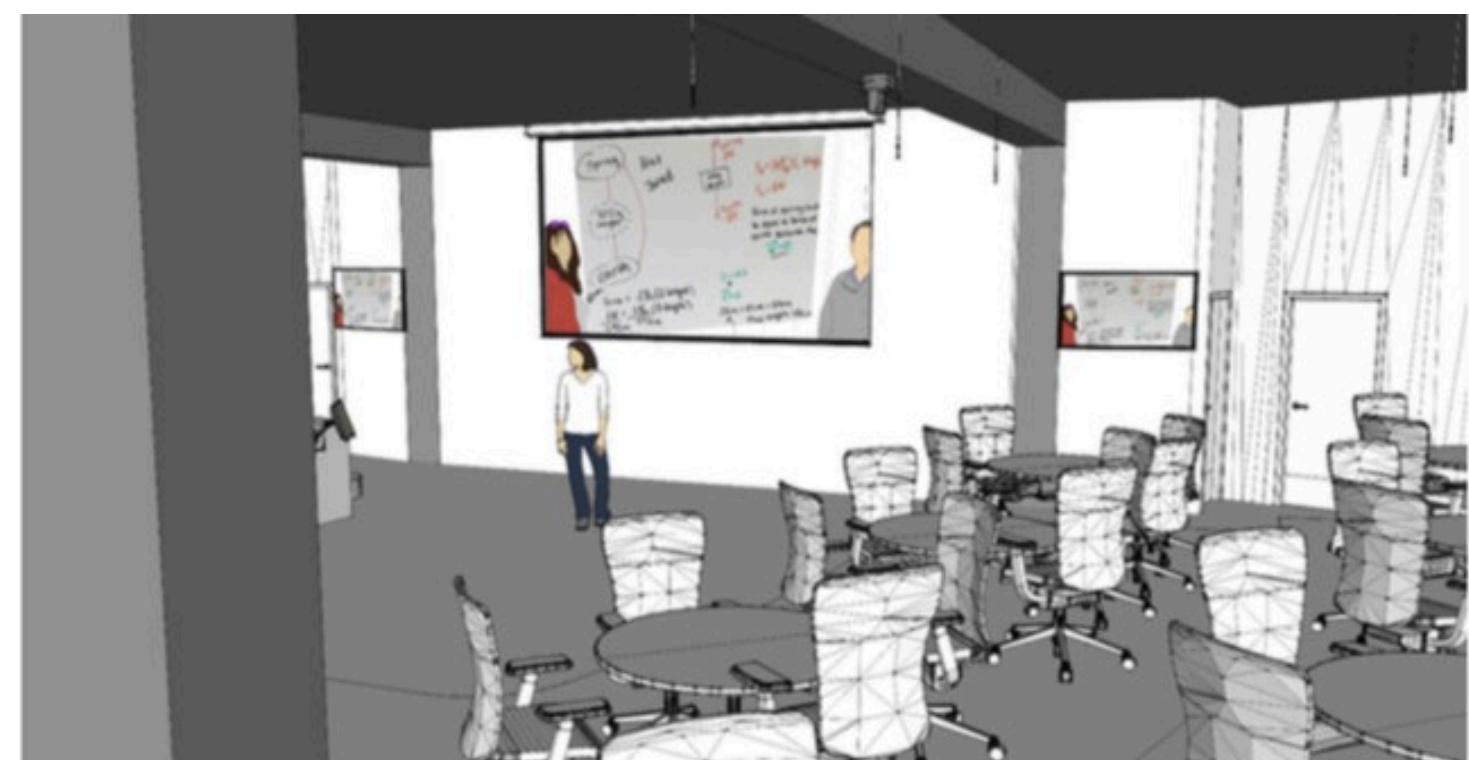

Figure 6. 3D Visualisation of the Cabaret Theatre - Audience right (near)

In considering how ideas on the blackboards would be shared, it was noted that students use smartphones to document and distribute group-developed content, and a wireless network presentation device was installed to connect mobile devices and platforms to displays in the room. However, due to the nature of remote participation and the needs of lecture recording and streaming, visual support for auditory dialogue needed further consideration. In addition, local participants would have access to a range of visual cues to track the shared focus of attention, and there was a desire to extend this affordance to remote learners. As a result, ceiling-mounted Pan-Tilt-Zoom (PTZ) cameras, controlled from the audiovisual touch panel, were 
installed. This had other benefits only noted after installation, including the ability to view learning activity via the preview monitor (see Figure 7) without disrupting group deliberations, and facilitating the sharing of ideas with local participants via the primary display and remote distribution to far-end virtual participants as well.

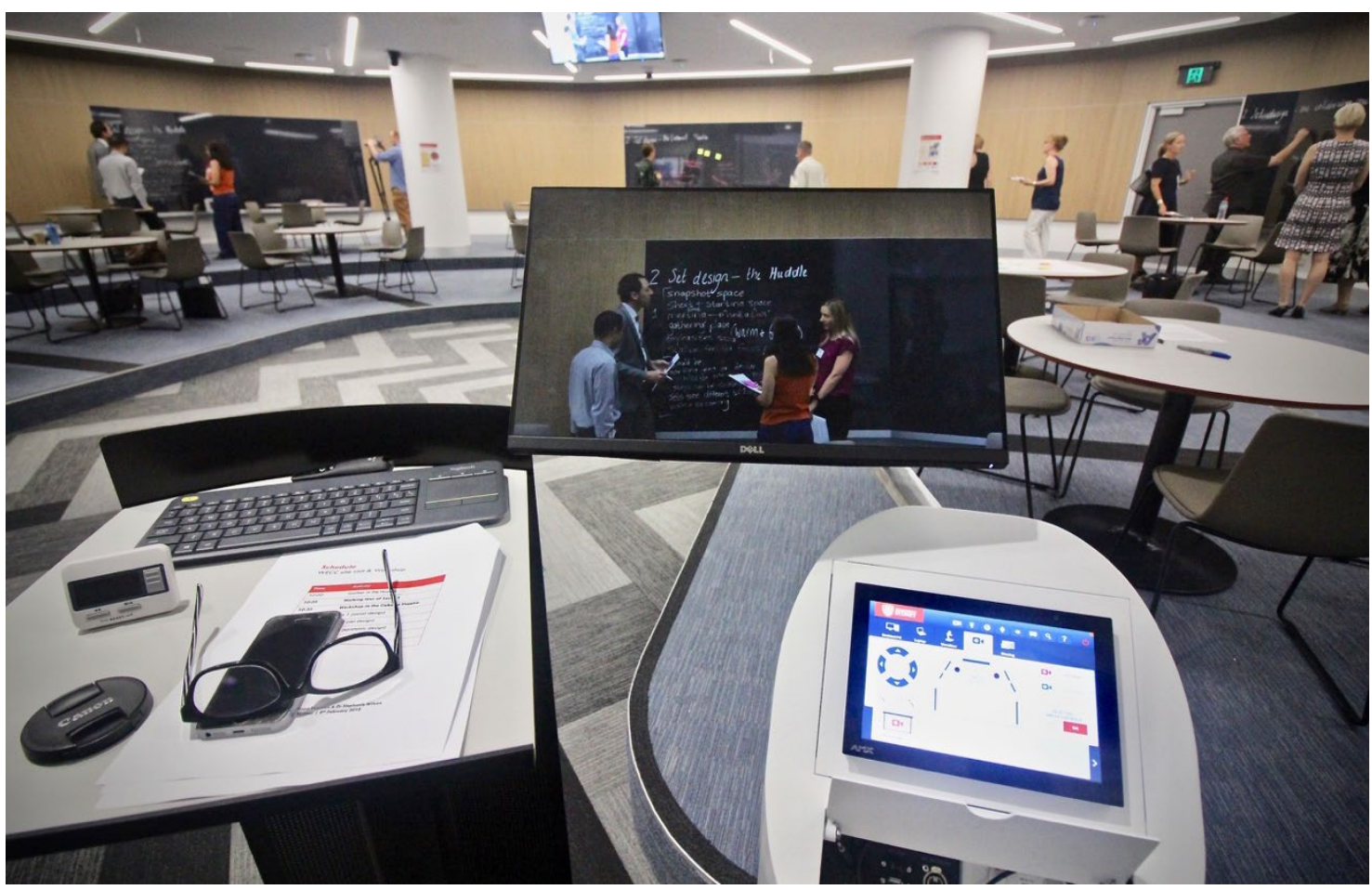

Figure 7. Final resolution in action in the Cabaret Theatre

Adaptation of the web conferencing facilities has been slow, due to a change in strategic direction coupled with a desire to simplify the tools available. A related optimisation of the system is required prior to adequate assessment of the space against project performance criteria, and this will be the focus of future reviews. Whilst dual displays featuring differing content in teaching spaces are typical and can be seen by local participants (pending appropriate design), extending this content remotely poses several challenges. Presenters must juggle two pieces of content, a camera, and questions from the floor, making the orchestration of learning activity less intuitive. In addition, the quality of connection for far-end users receiving up to three pieces of visual content results in multiple challenges that will ultimately diminish their experience. Based on the functional requirements of dialogue and connection, it was decided to use a single content source approach to support the highest degree of clarity when it came to local or remote presentation and recording. To ensure clear visual dialogue was maintained, the university's own viewed image size for audiovisual installations standard (Menon et al., 2017), which is an implementation of an international standard (Audiovisual and Integrated Experience Association, 2016), was employed. VIS-àVIS is a design standard to inform and respond to architecture, providing an objective measure to determine whether students are able to read an image with visual clarity. In this instance, the metrics were based on the functional requirements of the standard Basic Decision Making (Audiovisual and Integrated Experience Association, 2016), to support a minimum of $90 \%$ of the audience. These inputs relate to the typical functions of a larger teaching space, in which a resolution of $720 \mathrm{P}$ (1280 x 720 pixels) is considered adequate for basic decision making given the content and requirements of the space, based on an 18-point font being considered legible. The resolution of standard and architecture resulted in a need for relay displays to cater to the outer-most seated groups. An early concept measuring the viewing conformity of the space can be seen in Figure 6.

What we learn from design challenge 2 is that material properties have real and often confounding effects on teaching and learning practice; and that the time frames over which these projects evolve often result in shifting priorities for contributing stakeholders. Navigating this complexity requires tools capable of revealing underlying epistemic intentions, connecting material design with valued forms of emergent learning activity, and scaffolding wholistic responses to the challenges associated with designing and 
implementing satisfactory epistemic resolutions to a range of pedagogical challenges. We argue that Tables 4 through 6, and the lessons documented in design challenges 1 and 2, exemplify the fusing of professional practices (developed through observation, social interaction and material engagement), with largely invisible mental processes (including thinking, self-regulation and reflection), resulting in the development of epistemic perception in us and in epistemic tools for use by others in the future.

\section{Conclusion}

Our aims in writing were twofold: to make (1) a theoretical contribution by exploring a productive epistemic apprenticeship, and (2) a methodological contribution based on the analysis of the final design using the ACAD framework. Presented in the form of a case study, this article illustrates the give and take necessary in finding elegant spatial resolutions to complex future-oriented pedagogical problems. In mapping and reframing original epistemic intentions, tracing their persistence and expression in the final design, and exploring points of tension where epistemic intentions may have been subverted by competing material or social demands, we have opened a window on to what is often an invisible process. In so doing, we have developed "new kinds of traditions, at the intersection of the conceptual, social and material" (Markauskaite \& Goodyear, 2017, p. 360) by building on and generating "knowledge that is connected with material action and the socio-political concerns of communities" (p. 360). We have offered an example of epistemic apprenticeship in action - moving from a pedagogical challenge (how to support the adoption of new pedagogies), to an ergonomic challenge (supporting dialogue and shared sense-making in-person and online) which has resulted in a satisfactory epistemic resolution. We argue this offers the beginnings of a method for use in future projects involving the (re)design of space for learning, whilst acknowledging that in learning to exercise our epistemic perception we enjoyed access to a vast repository of academic and professional experience that extended far beyond the two of us.

The ability to imagine a particular form of future-oriented learning activity, and consider material design choices in relation to it, meant that finding workable solutions required more than simply accommodating various stakeholder's preferences. It required individual champions working to accommodate complex and often competing demands - across dimensions of designs and scale levels - or learning to exercise epistemic perception. All too often, innovation implies new technology and not new forms of the built environment or new forms of teaching and learning practice, and there were points when it seemed that digital connection would trump human connection. However, in this instance, the design as built is an elegant resolution of complex and often competing demands, which is evidence of the development of epistemic perception. This article covers the journey from design to implementation, and we are yet to explore how this design supports learning activity that is characterised by dialogue, mobility, and connection - both within and beyond its physical boundaries. Opportunities to build on this work include the potential integration of functional epistemic objects from one domain (electro-acoustic modelling) into the post-occupancy professional learning of another (education). We suggest that this type of adaptation and reuse of representations, which are essentially by-products of the design process, offers an as yet untapped source of epistemic tools that are particularly well suited to the task of translating epistemology into the built environment for learning.

\section{Acknowledgements}

Dr Yeoman's contributions to this work were supported by ARC Discovery Grant (DP150104163).

We would like to thank Professor David Cook who led the project and the wider project team, HDR Inc. and the University of Sydney for permission to reproduce Figures 2, 4, 5 and 6, Dr Garduno Freeman for the sketch reproduced in Figure 1, and the anonymous reviewer and editors for their help in refining this work.

\section{References}

Adams Becker, S., Cummins, M., Davis, A., Freeman, A., Hall Giesinger, C., \& Ananthanarayanan, V. (Eds.). (2017). NMC Horizon Report: 2017 higher education edition. Austin, TX: The New Media Consortium. Retrieved from https://www.nmc.org/publication/nmc-horizon-report-2017-highereducation-edition/ 
Audiovisual and Integrated Experience Association. (2016). Display image size for 2D content in audiovisual systems (AVIXAV202.01:2016). Fairfax, VA: Author. Retrieved from https://www.avixa.org/standards

Barrett, P., Zhang, Y., Moffat, J., \& Kobbacy, K. (2013). A holistic, multi-level analysis identifying the impact of classroom design on pupils' learning. Building and Environment, 59, 678-689. https://doi.org/10.1177/0013916516648735

Bayne, S. (2014). What's the matter with 'technology-enhanced learning'? Learning, Media and Technology, 40(1), 5-20. https://doi.org/10.1080/17439884.2014.915851

Blackmore, J., Bateman, D., Loughlin, J., O’Mara, J., \& Aranda, G. (2011). Research into the connection between built learning spaces and student outcomes (No. 22) (pp. 1-72). Melbourne: Department of Education and Early Childhood Development.

Brooks, D. C. (2010). Space matters: The impact of formal learning environments on student learning. British Journal of Educational Technology, 42(5), 719-726. https://doi.org/10.1111/j.14678535.2010.01098.x

Brooks, D. C., \& Solheim, C. A. (2014). Pedagogy matters, too: The impact of adapting teaching approaches to formal learning environments on student learning. New Directions for Teaching and Learning, 2014(137), 53-61. https://doi.org/10.1002/tl.20085

Carvalho, L., \& Yeoman, P. (2018). Framing learning entanglement in innovative learning spaces: Connecting theory, design, and practice. British Educational Research Journal, 44(6), 1120-1137. http://doi.org/10.1002/berj.3483

Castañeda, L., \& Selwyn, N. (2018). More than tools? Making sense of the ongoing digitizations of higher education. International Journal of Educational Technology in Higher Education, 15(22), 110. https://doi.org/10.1186/s41239-018-0109-y

Clark, A. (2010). Supersizing the mind. Oxford: Oxford University Press.

Cotner, S., Loper, J., Walker, J. D., Walker, G., \& Brooks, D. C. (2013). "It's not you, it's the room.” Are the high-tech, active learning classrooms worth it? Journal of College Science Teaching, 42(6), 1-8. Retrieved from https://www.jstor.org/stable/43632160

Goodyear, P., \& Carvalho, L. (2014). Framing the analysis of learning network architectures. In L. Carvalho \& P. Goodyear (Eds.), The architecture of productive learning networks (pp. 48-70). London: Routledge.

Higgins, S., Hall, E., Wall, K., Woolner, P., \& McCaughey, C. (2005). The impact of school environments (pp. 1-47). London: Design Council. Retrieved from http://www.ncl.ac.uk/cflat/about/documents/designcouncilreport.pdf

House of Commons Public Accounts Committee. (2009). Building schools for the future: Renewing the secondary school estate (Twenty-seventh report of session 2008-09). London: The Stationery Office Limited. Retrieved from https://publications.parliament.uk/pa/cm200809/cmselect/cmpubacc/274/274.pdf

Hutchins, E. (2014). The cultural ecosystem of human cognition. Philosophical Psychology, 27(1), 3449. https://doi.org/10.1080/09515089.2013.830548

Imms, W., \& Byers, T. (2016). Impact of classroom design on teacher pedagogy and student engagement and performance in mathematics. Learning Environments Research, 20(1), 139-152. https://doi.org/10.1007/s10984-016-9210-0

Ingold, T. (2011). Being alive. Abingdon: Routledge.

Ito, M., Soep, E., Kligler-Vilenchik, N., Shresthova, S., Gamber-Thompson, L., \& Zimmerman, A. (2015). Learning connected civics: Narratives, practices, infrastructures. Curriculum Inquiry, 45(1), 10-29. https://doi.org/10.1080/03626784.2014.995063

Janssen, F. J. J. M., Konings, K. D., \& van Merriënboer, J. J. G. (2017). Participatory educational design: How to improve mutual learning and the quality and usability of the design? European Journal of Education, 52(3), 268-279. https://doi.org/10.1111/ejed.12229

Konings, K. D., Bovill, C., \& Woolner, P. (2017). Towards an interdisciplinary model of practice for participatory building design in education. European Journal of Education, 52(3), 306-317. https://doi.org/10.1111/ejed.12230

Koutamanis, A., Heuer, J., \& Konings, K. D. (2017). A visual information tool for user participation during the lifecycle of school building design: BIM. European Journal of Education, 52(3), $295-305$. https://doi.org/10.1111/ejed.12226

Lave, J., \& Wenger, E. (1991). Situated learning. Cambridge: Cambridge University Press.

Markauskaite, L., \& Goodyear, P. (2017). Epistemic fluency and professional education. Dordrecht: Springer. 
Menon, P., Ashmore, N., Clarke, A., \& Thorpe, M. (2017). Viewed image size for audio visual installations standard (VISAVIS). Sydney, Australia: The University of Sydney, ICT AV Engineering.

New South Wales Parliament Legislative Council. (2010). The Building the Education Revolution Program (General Purpose Standing Committee No. 2, Report no. 35). Retrieved from https://www.parliament.nsw.gov.au/lcdocs/inquiries/2322/100920 final report.pdf

Oliver, M. (2012). Learning technology: Theorising the tools we study. British Journal of Educational Technology, 44(1), 31-43. https://doi.org/10.1111/j.1467-8535.2011.01283.x

Oxford English Dictionary. (2018). Vision. Retrieved from https://en.oxforddictionaries.com/definition/vision

Sørensen, E. (2009). The materiality of learning. Cambridge: Cambridge University Press.

Temple, P. (2007). Learning spaces for the 21st century. The Higher Education Academy, 1-84. Retrieved from https://www.heacademy.ac.uk/knowledge-hub/learning-spaces-21st-century

van Merriënboer, J. J. G., McKenney, S., Cullinan, D., \& Heuer, J. (2017). Aligning pedagogy with physical learning spaces. European Journal of Education, 52(3), 253-267. https://doi.org/10.1111/ejed.12225

Weinstein, C. S. (1979). The physical environment of the school. Review of Educational Research, 49(4), 577-610. https://doi.org/10.3102/00346543049004577

Wenger, E. (1999). Communities of practice. Cambridge: Cambridge University Press.

Yeoman, P. (2017). A study in improvisation, in the design and use of complex networked learning environments. In L. Carvalho, P. Goodyear, \& M. de Laat (Eds.), Place-based spaces for networked learning (pp. 41-59). New York, NY: Routledge.

Yeoman, P. (2018). The material correspondence of learning. In R. Ellis \& P. Goodyear (Eds.), Spaces of teaching and learning (pp. 81-103). Singapore: Springer Singapore. https://doi.org/10.1007/978-98110-7155-3_6

Corresponding author: Pippa Yeoman, pippa.yeoman@sydney.edu.au

Australasian Journal of Educational Technology (C) 2018.

Please cite as: Yeoman, P., \& Ashmore, N. (2018). Moving from pedagogical challenge to ergonomic challenge: Translating epistemology into the built environment for learning. Australasian Journal of Educational Technology, 34(6), 1-16. https://doi.org/10.14742/ajet.4502 